\title{
WHY DO ETHNIC GROUPS REBEL? New Data and Analysis
}

\author{
By LARS-ERIK CEDERMAN, ANDREAS WIMMER, and BRIAN MIN*
}

$\mathrm{D}$ ESPITE its fundamental role in legitimizing the modern state system, nationalism has rarely been linked to the outbreak of political violence in the recent literature on ethnic conflict and civil war. To a large extent, this is because the state is absent from many conventional theories of ethnic conflict. Indeed, some studies analyze conflict between ethnic groups under conditions of state failure, thus making the absence of the state the very core of the causal argument. Others assume that the state is ethnically neutral and try to relate ethnodemographic measures, such as fractionalization and polarization, to civil war. In contrast to these approaches, we analyze the state as an institution that is captured to different degrees by representatives of particular ethnic communities, and thus we conceive of ethnic wars as the result of competing ethnonationalist claims to state power.

While our work relates to a rich research tradition that links the causes of such conflicts to the mobilization of ethnic minorities, it also goes beyond this tradition by introducing a new data set that addresses some of the shortcomings of this tradition. Our analysis is based on the Ethnic Power Relations data set (EPR), which covers all politically relevant ethnic groups and their access to power around the world from 1946 through 2005. This data set improves significantly on the widely used Minorities at Risk data set, which restricts its sample to mobilized

\footnotetext{
*Correspondence should be directed to Lars-Erik Cederman (1cederman@ethz.ch). We would like to thank the many individuals who helped assemble the data set on which this article relies. We cannot list all country experts who generously shared their knowledge, but we should like to mention Dennis Avilés, Yuval Feinstein, Dmitry Gorenburg, Wesley Hiers, Lutz Krebs, Patrick Kuhn, Anoop Sarbahi, James Scarritt, Manuel Vogt, Judith Vorrath, Jürg Weder, and Christoph Zürcher. Luc Girardin implemented the software for the online expert survey. The authors acknowledge financial support from the Swiss National Science Foundation through Grant No. 105511-116795, and from UCLA's International Institute. We are grateful for helpful comments by the editors and anonymous referees of this journal, Kristian Skrede Gleditsch, Simon Hug, and Idean Salehyan, as well as audiences at EтH Zürich, the Graduate Institute of International Studies in Geneva, Hebrew University in Jerusalem, University of St. Gallen, and Princeton University.
}

World Politics 62, no. 1 (January 2010), 87-119

Copyright (C) 2010 Trustees of Princeton University

doi: $10.1017 /$ S0043887109990219 
minorities and thus largely overlooks the ethnopolitical constellation of power at the center.

Improved theory and data allow us to show that, contrary to the expectations held by many scholars of civil wars, competing ethnonationalist claims over the state constitute the driving force behind many internal conflicts in the post-World War II era. While we have analyzed this data set at the country level in another publication, ${ }^{1}$ we pursue a more disaggregated, group-level analysis here. We show that conflict with the government is more likely to erupt (1) the more representatives of an ethnic group are excluded from state power, especially if they experienced a loss of power in the recent past, (2) the higher their mobilizational capacity is, and (3) the more they have experienced conflict in the past. In view of these findings, we conclude that ethnonationalist struggles over access to state power are an important part of the dynamics leading to the outbreak of civil wars.

The article is organized as follows. We first review the relevant conflict literature and then develop the three main hypotheses that lie at the core of our theory. The following section introduces the EPR data set. The main results are presented in the next section, followed by a brief sensitivity analysis and a concluding section.

\section{Existing Approaches to Ethnicity and Conflict: Security Dilemma, Ethnic Fractionalization, and Minority MobiLization}

In order to understand the conflicts that broke out in Yugoslav and Soviet successor states as well as in Rwanda during the 1990s, some researchers have utilized ideas developed to study interstate relations during the cold war. Most prominently, Posen conceived of ethnic conflict as a struggle between ethnic groups in the wake of state collapse. ${ }^{2}$ According to neorealist theory, ethnic groups face a security dilemma when the Leviathan disappears and react with preemptive violence. These ideas were subsequently elaborated with the help of rational choice models. $^{3}$

As a consequence of the assumption of state breakdown, however, this research tends to overlook the important role played by state actors

${ }^{1}$ Complementing the current study, Wimmer, Cederman, and Min 2009 show that ethic conflict results from specific ethnopolitical configurations of power, rather than from ethnic diversity per se. They identify three particularly conflict-prone configurations: ethnocracies, states with a high number of power-sharing ethnic elites, and incohesive states with a short history of direct rule by the center.

${ }^{2}$ Posen 1993.

${ }^{3}$ Hardin 1995; de Figueiredo and Weingast 1999. 
in generating these conflicts in the first place, as the wars in Yugoslavia, Rwanda, and many other places clearly demonstrate. In the absence of state agency, political violence may take the form of communal conflict over land or local political dominance but not of full-fledged civil war.

In recent statistical research on civil wars, many scholars argue that ethnic grievances are too widespread to explain the rare onset of conflict. Wars are more likely, so the argument goes, in states that are too weak to suppress rebellions or where natural resources invite warlords to enrich themselves by looting. ${ }^{4}$ Research on the basis of this grievance hypothesis has undoubtedly helped to clarify the general conditions that are conducive to civil wars and insurgencies. However, the grievance hypothesis has not been tested with adequate data; rather, it has been tested with highly aggregated proxies that do not provide a direct measure of political inequality along ethnic lines and the resulting "grievances." Fearon and Laitin, for example, examine whether there is a statistical association between measures of a country's "ethnic fractionalization" and civil war onset. ${ }^{5}$ Some scholars have worked with measures of ethnic polarization that are loosely related to Horowitz's theory of ethnic conflict, again without explicit references to the state. ${ }^{6}$ Others seek to operationalize the concept of ethnic domination but use a demographic proxy as well. ${ }^{7}$

We believe that efforts to grasp the propensity for ethnonationalist conflict with the help of macrolevel indices are problematic. ${ }^{8}$ First, they implicitly assume that the ethnic groups listed in the work of anthropologists and linguists are politically relevant. ${ }^{9}$ Second, the macrolevel indices describe a country's demography, ${ }^{10}$ which may or may not be related to the actual constellation of power at the state center. ${ }^{11}$ Qualitative studies of ethnic conflict show that in such cases the state is not an ethnically neutral institution but is an active agent of political exclusion that generates these conflicts in the first place. ${ }^{12}$

\footnotetext{
${ }^{4}$ Collier and Hoeffler 2004; Fearon and Laitin 2003; for a review, see Kalyvas 2007.

${ }^{5}$ Fearon and Laitin 2003. Using different model specifications, other quantitative studies report a positive impact of ethnic fractionalization on civil war onset; see Sambanis 2001; Hegre and Sambanis 2006; Blimes 2006.

${ }^{6}$ For example, Montalvo and Reynal-Querol 2005; cf. Horowitz 1985.

${ }^{7}$ For example, Collier and Hoeffler 2004.

${ }^{8}$ A number of scholars have called for a more disaggregated approach that focuses on microlevel mechanisms, for example, Kalyvas 2006; for a review, see Tarrow 2007. Our own approach complements these studies at a level of analysis that is less detailed yet offers global coverage.

${ }^{9}$ Posner 2004.

${ }^{10}$ Chandra and Wilkinson 2008.

${ }^{11}$ Cederman and Girardin 2007.

${ }^{12}$ Brass 1991; Breuilly 1994; Wimmer 2002.
} 
A third stream of research starts from this insight and studies the conditions under which minorities will mobilize against the state and also the conditions under which such mobilization will turn violent. ${ }^{13}$ Building on work in the relative deprivation tradition, the Minorities at Risk (MAR) data set established by Gurr and his colleagues remains the most prominent data source used to evaluate ethnic mobilizations and violence at the group level. ${ }^{14}$ Scholars in this tradition have studied the consequences economic, political, and cultural discrimination (see below), the settlement patterns that enhance minority mobilization for conflict, ${ }^{15}$ domestic diversion mechanisms, ${ }^{16}$ the dynamics of secessionist bargaining, ${ }^{17}$ and third-party intervention, ${ }^{18}$ as well as the role of country-level factors, such as government responses to autonomy claims by ethnic minorities ${ }^{19}$ and broader international contextual factors facilitating ethnic mobilization. ${ }^{20}$

While the MAR data set allows for empirical testing of mechanisms linking group characteristics to conflict propensity, it has its limitations. We note that the MAR-based literature has produced somewhat conflicting results regarding the question most relevant to this article: whether or not political disadvantage and discrimination increase the likelihood of ethnic rebellion. In fact, whereas some studies find that political disadvantage has an impact on the likelihood of armed rebellion and secession, ${ }^{21}$ others find that the degree of political exclusion has no effect on secessionism. ${ }^{22}$ The picture is even more mixed as regards the effect of political discrimination: while Regan and Norton, as well as Walter, find strong evidence that political discrimination increases rebellions and secessionist civil wars, ${ }^{23}$ Fox fails to find any clear relationship for the subset of ethnoreligious groups, ${ }^{24}$ and Gurr's study of ethnonationalist rebellions in the 1980s even suggests that political discrimination is associated with less rather than more conflict. ${ }^{25}$ Olzak aggregates MAR data on the country level and arrives at the conclusion

${ }^{13}$ There is also a vast qualitative literature on minority mobilization and ethnonationalist violence; see Brubaker and Laitin 1998.

${ }^{14}$ Gurr 1993a; Gurr 2002.

${ }^{15}$ Toft 2003.

${ }^{16}$ Tir and Jasinski 2008.

${ }^{17}$ Walter 2006a; Jenne 2007.

${ }^{18}$ Cetinyan 2002; Saideman 2002.

${ }^{19}$ Brancati 2006; Walter 2006b.

${ }^{20}$ Olzak 2006.

${ }^{21}$ For example, Gurr 1993b; Walter 2006b.

${ }^{22}$ Saideman and Ayers 2000.

${ }^{23}$ Regan and Norton 2005; Walter 2006b.

${ }^{24}$ Fox 2000.

${ }^{25}$ Gurr 1993b. 
that both formal recognition of ethnic group rights and political discrimination increase the likelihood of conflict. ${ }^{26}$

Clearly, some of these discrepancies can be attributed to different research designs and sample definitions, but we suspect that the data set's inherent problems might be responsible for these conflicting findings as well. The MAR data set "hardwires" the degree of power access into the sample definition by excluding groups in power from systematic consideration. This reduces the comparative horizon and thus makes it harder to capture the effects of political exclusions in unambiguous ways. Moreover, in many countries with dramatic shifts in power constellations (Chad, Afghanistan, Liberia), the political status of an ethnic group may change from discriminated minority to ruling elite from one period to the next. Indeed, studies of ethnonationalism should treat ethnic groups' representation within government as a variable rather than as a constant. Finally, focusing on minorities conflates the demographic concept of numerical domination with political exclusion. Accordingly, the MAR coding scheme does not fit countries with ruling minorities or complex coalitions of ethnically defined elites, as for example in Nigeria, India, or Chad, where ethnic conflict will be pursued in the name of excluded majorities (rather than minorities) or ethnic groups that share power (and are thus not "at risk"). ${ }^{27}$

In sum, much of the recent literature on ethnic conflict and civil wars fails to get the state's role right. Many approaches do not take account of the state as an actor in conflict processes (as in the security dilemma approach), fail to trace the ethnopolitical power constellations at the center of state power (as in the minority mobilization school), or try to capture ethnopolitical discontent through demographic proxies of diversity. These theoretical, sampling, and measurement problems hinder the development of precise and testable hypothesis about which mechanisms connect ethnonationalist politics to political violence. The following section addresses this task.

\section{Theorizing Ethnonationalist Conflict: Actor Constellations, Motives, and Collective Action}

The classical sociological literature on nationalism offers a good starting point for understanding the logic of ethnonationalist conflict.

${ }^{26}$ Olzak 2006,124.

${ }^{27}$ The MAR data set tries to address these limitations by including five "advantaged" minorities that benefit from political discrimination. MAR also comprises a series of "communal contenders" mostly in Africa, that is, groups that share power with others while at the same time mobilizing in protest or rebellion. 
Nationalism can be defined as a political principle that demands that the unit of governance and the nation should be congruent. It replaces the principle of dynastic sovereignty on which agrarian empires were based. ${ }^{28}$ Whereas the unit of governance is usually understood to be the sovereign state, the nation is imagined as a community of common origin and shared historical destiny. ${ }^{29}$

In the modern era the introduction of the principles of nationalism-that ethnic likes should rule over ethnic likes-has led to waves of political mobilizations and a subsequent transformation of the state system. ${ }^{30}$ The ensuing ethnonationalist struggles have taken on a variety of forms: conflict over access to state power between the leaders of competing ethnic communities, ${ }^{31}$ secession from existing states in order to establish a new state ruled in the name of a particular ethnic group $^{32}$ or to join another state controlled by ethnic kin, ${ }^{33}$ and competition between new states over mixed territories inhabited by members of their respective ethnic core groups. ${ }^{34}$

While this literature helps to explain the broad historical and political circumstances under which we can expect ethnonationalist mobilization and conflict, it is much less concerned with identifying the precise mechanisms through which such ethnonationalist mobilization turns violent. Only recently have a number of scholars turned to studying nationalist mobilization and conflict in greater detail. ${ }^{35}$ We selectively draw on this scholarship in order to develop our own model of ethnonationalist conflict.

Our analytical point of departure is Tilly's polity model, which features a political system comprising a government and a number of contenders seeking to maximize their access to executive power. ${ }^{36}$ Members of the polity enjoy a privileged position, while those excluded from direct access to government represent potential challengers (see Figure 1). Adapting Tilly's model along the lines proposed by Cederman and Girardin, we assume that polity members and challengers consist of ethnic groups and their leaders (including politically irrelevant groups

${ }^{28}$ Gellner 1983.

${ }^{29}$ Anderson 1991.

${ }^{30}$ Kedourie 1960; Breuilly 1994; Brubaker 1996; Cederman 1997; Wimmer and Min 2006.

${ }^{31}$ For example, Brass 1991; Wimmer 2002.

${ }^{32}$ For example, Hechter 2001.

${ }^{33}$ For example, Weiner 1971.

${ }^{34}$ For example, Brubaker 1996.

${ }^{35}$ For example, Beissinger 2002; Cederman 1997, chaps. 7, 8; Hechter 2000; Olzak 2006; Wimmer 2002, chap. 3 .

${ }^{36}$ Tilly 1978. 


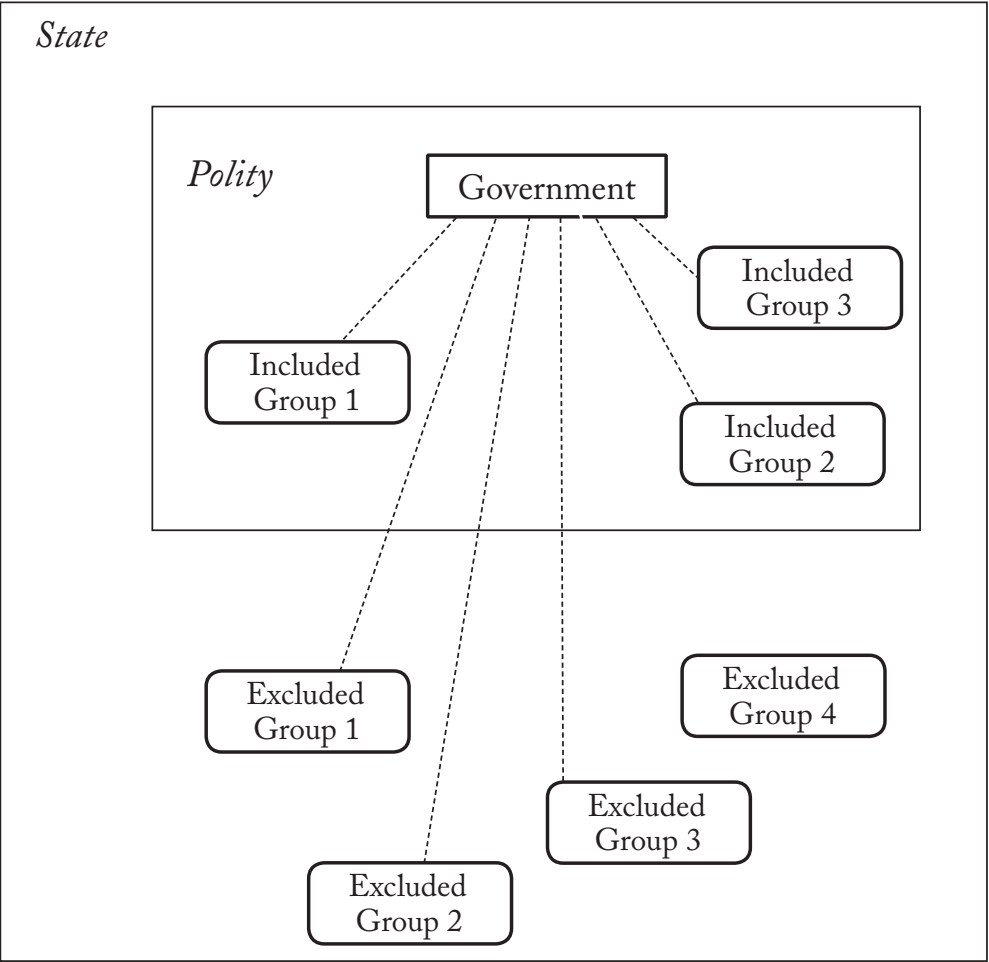

FIGURE 1

The Polity Model with Included and Excluded Ethnic Groups

such as group 4). ${ }^{37}$ Given the principle of ethnonational representativity embodied by the modern nation-state, it can be expected that challengers seek to avoid the rule of ethnic others by gaining access to the polity or leaving it in favor of a new polity or an already existing kin state. Power holders should want to maximize their share of state power - thus opening the possibility of infighting among powersharing partners.

Civil wars confront incumbent governments with political and military organizations that challenge the governments' claim to sovereign rule. This situation corresponds to standard definitions of civil $\mathrm{war}^{38}$ but excludes communal conflicts or pogroms in which the state plays less of an active role. In conflicts that are fought in the name of excluded groups, rebel movements are composed of mobilized and militarized

${ }^{37}$ Cederman and Girardin 2007 refer to "Ethnic Groups in Power" (EGIPs) and "Marginalized Ethnic Groups" (MEGs).

${ }^{38}$ Sambanis 2004; Kalyvas 2007. 
organizations that challenge the government. In the case of challenges launched in the name of groups that are already represented within government, other actors such as a faction within the army or newly created political organizations and militias might instigate a violent confrontation.

Having identified the main actors and the types of conflicts they may provoke, we now consider the conditions under which violence is most likely to erupt. We first study which groups will be more motivated to support a rebellion against ethnic domination by others. Indeed, many aggrieved groups have not produced militant rebel organizations. We therefore have to identify those groups that perceive the government as particularly illegitimate and are therefore more inclined to support rebellions. Second, we consider a group's organizational capacity to challenge incumbent state power because high levels of motivation alone will not suffice to produce an armed organization willing to take on the government army. Finally, rather than constituting historical singularities, political violence often leaves traces that put nationalist politics on a contentious track. We therefore need to identify such potential effects of path dependency. In the following, we consider the causal mechanisms associated with each of these three mechanisms in turn.

\section{Most Motivated Groups: Excluded, Downgraded, AND UNDERREPRESENTED}

To specify motives and identify the most motivated actors, we draw on Wimmer's institutionalist approach to nationalism and ethnic politics, which assumes that rulers in modern nation-states are no longer legitimized by the principles of dynastic succession, God's grace, or civilizational progress but that they are expected to care for their own, ethnically defined people. ${ }^{39}$ Political officeholders thus have institutional incentives to gain legitimacy by favoring coethnics over others when it comes to the distribution of public goods and government jobs. The expectation of ethnic preference works in the other direction as well, as voters prefer parties led by coethnics, delinquents hope for coethnic judges, and citizens prefer to be policed by coethnics.

Under the conditions of pervasive ethnic favoritism, political leaders and followers are driven by the strategic motive to avoid or even to overturn dominance by ethnic "others." This motive is simultaneously material, political, and symbolic: "adequate" or "just" representation in a central government offers material advantages such as access

${ }^{39}$ Wimmer 2002. 
to government jobs and services, legal advantages such as the benefits of full citizenship rights, a fair trial, and protection from arbitrary violence, and symbolic advantages such as the prestige of belonging to a "state-owning" ethnic group. In brief, this approach conceives of ethnic politics as the struggle over control of the state between various ethnically defined organizations and their constituencies. Especially in weak states with weakly developed civil societies, the state may be captured by particular ethnic elites and their constituencies, thus giving rise to one among other variants of the "weak state-strong society" constellation analyzed by Midgal and others. ${ }^{40}$

It follows that groups that lose out in this struggle for state power are more fertile breeding grounds for organizations that challenge the government. We postulate a direct relationship between the degree of state power and the likelihood that an armed rebellion will be instigated in the name of that particular group. The most excluded groups will thus be most likely to support armed organizations that challenge the government. Given nationalist principles of political legitimacy, feelings of resentment will be widespread and can be channeled into successful collective action. ${ }^{41}$ We summarize this reasoning in a first hypothesis:

-H1a. The probability of ethnonationalist conflict increases the more representatives of an ethnic group are excluded from central executive power.

The exclusion mechanism also alerts us to the consequences of changes in power hierarchies. Sociological theories of emotions suggest that negative emotions are especially likely to be aroused following loss of power and prestige. ${ }^{42}$ When the subjects blame others for their downgrading, anger and resentment increase the readiness to fight in order to change the situation. ${ }^{43}$ We postulate a similar mechanism at the level of collective organizations: leaders of ethnonationalist organizations will be most likely to resort to violence if they have recently experienced a loss of relative power. They can channel the resentment of their constituencies and mobilize to "reverse a reversal." ${ }^{44}$ This reasoning leads to the following hypothesis:

${ }^{40}$ Migdal 1988; see also Jackman 1993.

${ }^{41}$ Petersen 2002.

${ }^{42}$ Kemper 1978.

${ }^{43}$ Turner and Stets 2005, 217

${ }^{44}$ Petersen 2002, 173. The MAR data set includes an indicator for "lost autonomy" that is associated with rebellions; see Gurr 2000, 230; Saideman and Ayres 2000; Walter 2006b. Note, however, that our hypothesis concerns all types of status reversals, including exclusion or demotion that were not preceded by autonomous status. 
-H1b. The probability of ethnonationalist conflict increases following a fall in power status that decreases access to central executive power by representatives of an ethnic group.

Finally, the principle of ethnic representativity of modern nationstates is also violated if groups in power are "underrepresented" in comparison with other power-sharing partners. When smaller groups wield more power than larger groups, representatives of the larger groups can portray the situation as unfair and stir up fear of ethnic domination among their constituents. ${ }^{45}$ Thus, we have the next hypothesis.

-H1c. The probability of ethnonationalist conflict increases if the ethnic group represented by a power-sharing partner is larger compared with that of more powerful coalition partners.

\section{Mobilizational Capacity: Group Size}

Collective action theory tells us that group motivations are insufficient to produce political mobilization and violent contestation. ${ }^{46}$ The motivational forces described above are thus a necessary, but not a sufficient, cause for ethnic conflict. Successful mobilization requires both motivation and organizational capacity. ${ }^{47}$ While neoclassical collective action theory in the Olsonian tradition expects free riding in large groups, nationalists may overcome such dilemmas through intragroup monitoring, by relying on preexisting social networks, and by mobilizing identity-related cooperation norms ${ }^{48}$ Following resource mobilization theory, we postulate that larger excluded groups are even more able to challenge a government because they can draw on their superior numbers to recruit fighters and have a larger potential resource pool to sustain an organizational infrastructure. ${ }^{49}$ As argued by Cederman, Buhaug, and Rød, the political claims of larger ethnic groups also enjoy more legitimacy: given the principles of representativity that underlie the nation-state, the exclusion of large sections of the population from power is more scandalous than the exclusion of smaller groups, and minority-ruled states (ethnocracies) are among the least legitimate political regimes in the modern world..$^{50}$ Based on this argument, we postulate the next hypothesis.

$-\mathrm{H} 2$. The probability of ethnonationalist conflict increases with the ethnic group's relative demographic size.

\footnotetext{
${ }^{45}$ For a general argument based on intergroup comparison, see Horowitz 1985; and Gurr 2000.

${ }^{46}$ McCarthy and Zald 1977; Tilly 1978; Tilly and Tarrow 2006.

${ }^{47}$ Gurr 2000.

${ }^{48}$ Hechter and Okamoto 2001. Furthermore, free riding may be less problematic in many civil war situations because of the risks associated with nonparticipation; see Kalyvas and Kocher 2007.

${ }^{49}$ McCarthy and Zald 1977; DeNardo 1985.

${ }^{50}$ Cederman, Buhaug, and Rød 2009; see also Cederman 1997, chap. 8; Petersen 2002, 51.
} 


\section{History Matters: The Influence of Past Conflict}

Ethnonationalist mobilization and contestation are macrohistorical processes that operate over both short ${ }^{51}$ and long time spans. ${ }^{52}$ It may take decades until perceived humiliation and unfair ethnic status hierarchies give rise to political mobilization and conflict. Thus, rather than being an instant and ahistorical phenomenon, nationalist mobilization takes place in a historical context that might be characterized by previous episodes of ethnonationalist violence. In extreme cases of path dependency, actors may find themselves trapped in self-sustaining cycles of violence.

We postulate that past conflicts influence the likelihood of present conflict through three mechanisms. First, ethnonationalist activists attempt to glorify their group's history through one-sided narratives that stress their own victories and attribute blame for military losses to traitors, weak-spirited leaders, or a ruthless enemy. This implies that leaders might not update their risk assessments and might take up arms again even when the chances of winning have not improved significantly. ${ }^{53}$ Second, past experiences of traumatic violence may live on as a part of oral tradition or they may sometimes be perpetuated in official history textbooks and public rituals, nourishing calls for revenge. ${ }^{54}$ Third, prior exposure to combat means that violence is no longer unthinkable but constitutes part of the accepted repertoire of action and may help create organizational structures and identities that can be reactivated at later points in history or even create a culture of violence. ${ }^{55} \mathrm{We}$ express these three mechanisms of path dependency in our third main hypothesis.

$-\mathrm{H} 3$. The probability of ethnonationalist conflict increases with the number of prior conflicts fought in the name of the same ethnic group.

Needless to say, this set of hypotheses does not exhaust the links between ethnicity and internal conflict. Properties of ethnic groups, such as concentrated settlement patterns, ${ }^{56}$ cohesive internal structure, ${ }^{57}$ and

${ }^{51}$ Beissinger 2002.

${ }^{52}$ Wimmer and Min 2006.

${ }^{53}$ Rydgren 2007.

${ }^{54}$ Kalyvas 2007.

${ }^{55}$ Laitin 1995; Waldman 2004. For alternative explanations of recurrent warfare, see Walter 2004. Conflict experiences involving other groups may also increase the likelihood of ethnonationalist violence through diffusion mechanisms; see Lake and Rothchild 1998.

${ }^{56}$ Using the GREG (Geo-Referencing Ethnic Groups) data set, which is based on a geo-coded version of the Atlas Narodov Mira, Weidmann 2009 shows that there is a strong link between settlement concentration and conflict, thus confirming Toft 2003. Data collection that will provide a GIs-based version of EPR is under way.

${ }^{57}$ Tilly 1978; Gurr 2000. 
availability of external support, ${ }^{58}$ are known to increase the probability of civil wars, but investigating these factors requires data that are presently unavailable in our data set.

Before operationalizing and testing our main hypotheses, we turn to the data set that underlies this study. Evaluating the theory calls for data that code access to executive power for representatives of different ethnic groups, as well as the conflicts in which they have been involved.

\section{Measuring Ethnic Power Relations}

The Ethnic Power Relations (EPR) data set identifies all politically relevant ethnic groups and their access to state power in all years from 1946 to $2005 .{ }^{59}$ In collecting the data, we relied on the expert input of nearly one hundred students of ethnic politics to assess formal and informal degrees of political participation and exclusion along ethnic lines. ${ }^{60} \mathrm{In}$ line with most other data sources on ethnic politics including MAR, the current data set takes ethnic groups as units of observation, rather than political organizations that claim to speak in their name. ${ }^{61}$ This data set improves significantly on previous efforts to code ethnic groups' access to power, such as that of Cederman and Girardin, who rely on static measures of inclusion and limit their sample to Eurasia and North Africa. ${ }^{62}$

\section{Politically Relevant Ethnic Groups}

We define ethnicity as any subjectively experienced sense of commonality based on the belief in common ancestry and shared culture. ${ }^{63}$ Differ-

${ }^{58}$ The coding of transborder links among groups represented in EPR is in progress. Based on the GREG data set, Cederman, Girardin and Gleditsch 2009 find a size-dependent kin effect within Eurasia. For a more general treatment of transnational factors of civil wars, see Salehyan 2009.

${ }^{59}$ The EPR data set, which can be downloaded from http://dvn-iq.harvard.edu/dvn.dv/epr, is described fully with complete coding rules in Min, Cederman, and Wimmer 2009 and in an online appendix. The data set includes politically relevant ethnic groups in all 155 sovereign states with a population of at least one million and a surface area of at least five thousand square kilometers as of 2005 .

${ }^{60}$ The process of contacting and interacting with country experts took almost two years. Once sufficient coding responses were available, workshops were held to decide on the final coding. We discussed each coding in light of comments from the experts present, as well as of information from additional data sources and the accumulating comparative knowledge of the project team itself.

${ }^{61}$ The main reason for this methodological decision is that governmental and rebel organizations are much more prone to change (for example, through processes of fusion, fission, exit, and entry) than politically relevant ethnic groups, requiring more intricate organization-level data than are currently available (but see the preliminary efforts currently under way at MAR). Recently efforts have been made to code nonstate actors in civil wars, but in such cases the focus is on rebel organizations and thus excludes political organizations in nonconflict cases; see, for example, Cunningham, Gleditsch, and Salehyan 2009.

${ }^{62}$ Cederman and Girardin 2007; Buhaug, Cederman, and Rød 2008; though see Cederman, Buhaug, and Rød 2009 for a global analysis.

${ }^{63}$ Weber 1978, 385-98. The following definition of ethnicity relies on Wimmer 2008. 
ent markers may be used to indicate such shared ancestry and culture: common language, similar phenotypical features, adherence to the same faith, and so on. ${ }^{64}$ Ethnic groups might be hierarchically nested; that is, they may comprise several levels of differentiation, not all of which are necessarily politically relevant. We classify an ethnic group as politically relevant if at least one political organization claims to represent it in national politics or if its members are subjected to state-led political discrimination. ${ }^{65}$ Discrimination is defined as political exclusion directly targeted at an ethnic community-thus disregarding indirect discrimination based, for example, on educational disadvantage or discrimination in the labour or credit markets. The coding rules allow for the identification of countries or specific periods in which national politics was framed in nonethnic terms. ${ }^{66}$

To capture temporal changes in the set of politically relevant groups and their access to political power, the sample period from 1946 to 2005 was divided into subperiods, for which separate codings were provided. The next important step was to code the degree of access to power by the political leaders representing these various ethnic communities.

\section{Coding Access to Power}

The power-access coding is limited to executive power only. ${ }^{67}$ Depending on a given country's power constellations, executive power amounts to control over the presidency, the cabinet, and senior posts in the administration, including the army. Experts were encouraged to capture the most relevant dimension (for example, in a military dictatorship, power over the army, and in presidential systems, the presidency, and so on). We were interested primarily in major power shifts rather than day-to-day reorganizations of cabinets, limiting ourselves to absolute access to power irrespective of demographic underrepresentation or overrepresentation.

All politically relevant ethnic groups were categorized according to (1) whether those who claimed to represent a group's interest held full control of the executive branch with no meaningful participation

\footnotetext{
${ }^{64}$ We thus include ethnolinguistic, ethnosomatic (or "racial"), and ethnoreligious groups in our definition of ethnicity, but we exclude tribes and clans that define community in genealogical terms, as well as regions that do not define commonality on the basis of shared ancestry.

${ }^{65}$ It should be noted that political relevance does not equal violent conflict. Endogeneity is not a problem because only a tiny fraction of years with mobilized or discriminated groups were characterized by conflict ( 0.45 percent); cf. Posner 2004 .

${ }^{66}$ We did not distinguish between degrees of representativity of political actors who claim to speak in the name of an ethnic group; nor did we code the heterogeneity of political positions voiced by leaders claiming to represent the same community. Cf. Brubaker 2004.

${ }^{67}$ This choice was made in order to limit the coding effort. Legislative politics may also influence the likelihood of conflict through ethnic political parties and specific types of electoral institutions; see, for example, Cohen 1997; Brancati 2006; and Birnir 2007.
} 
by members of any other group, (2) whether they divided power with members of other groups in a power-sharing regime, or (3) whether they were excluded altogether from decision-making authority within the halls of central state power. Within each of these categories, coders were asked to differentiate between further subtypes.

\section{ABSOLUTE POWER}

In this case, the political elites that claim to represent an ethnic group do not significantly share power with other political leaders. There are two possibilities:

-Monopoly. Elite members hold monopoly power in the executive to the exclusion of members other ethnic groups.

-Dominance. Elite members of the group hold dominant power in the executive but there is some limited inclusion of "token" members of other groups.

POWER-SHARING REGIMES

By power sharing, we mean any formal or informal arrangement that divides executive power among leaders who claim to represent particular ethnic groups. Depending on the relative importance of the positions controlled by group representatives, there are two possibilities:

-Senior Partner. Representatives participate as senior in a formal or informal power-sharing arrangement.

-Junior Partner. Representatives participate as junior partners in government.

\section{EXCLUSION FROM CENTRAL POWER}

Finally, if political leaders who claim to represent a particular ethnic category are excluded from participation in central government, we distinguish between four possibilities:

-Regional Autonomy. Elite members of the group have no central power but some influence at the substate level, that is, one level below the central government. This may be the substate, the provincial, or the district (though not the local) level, depending on the vertical organization of the state.

- Separatist Autonomy. A related case is when local governments controlled by representatives of an ethnic category have declared their territory to be independent from the central government. This category differs fundamentally from "regional autonomy" in that group representatives have often excluded themselves from central state power.

-Powerless. Elite representatives hold no political power at either the national or the regional level without being explicitly discriminated against. 
-Discrimination. Group members are subjected to active, intentional, and targeted discrimination, with the intent of excluding them from both regional and national power. Such active discrimination can be either formal or informal. ${ }^{68}$

\section{Conflict Coding}

Our coding of conflict is based upon the UCDP/PRIO Armed Conflicts Dataset, which defines internal conflict as any armed and organized confrontation between government troops and rebel organizations or between army factions that reaches an annual battle death threshold of twenty-five. ${ }^{69}$ This definition excludes one-sided conflicts, such as massacres and genocides, as well as communal riots, pogroms, and other nonstate conflicts. ${ }^{70}$

For each conflict, we coded whether actors pursued ethnonationalist aims and whether they pursued secessionist objectives: Ethnic/Nonethnic Conflicts were distinguished by the aims of the armed organization on the one hand and their recruitment and alliance structures on the other hand. Ethnic aims include self-determination, more influence for one's group over government, autonomy, and language and other cultural rights. Regarding recruitment and alliance structures, we defined ethnic wars as fought by armed organizations who predominantly recruit fighters among their leaders' own ethnic group and who forge alliances on the basis of ethnic affiliation. For a conflict to be classified as ethnic, armed organizations must both explicitly pursue ethnonationalist aims and recruit fighters and forge alliances on the basis of ethnic affiliations.

All ethnic conflicts were then linked to the politically relevant ethnic group in the name of which an armed organization instigated the conflict. We looked at the aims and recruitment patterns of each armed organization separately. In some complex cases (as in Afghanistan, Burma, Chad, Uganda, Angola, and Zaire), we disaggregated a conflict into several war fronts when different ethnic claims were made on the nongovernmental side. This was also necessary when the constellation of rebel organizations and the ethnic communities they represented changed dramatically over time. ${ }^{71}$

Our data set includes 124 ethnic conflicts fought between 1946 and 2005. Given that some of these ethnic conflicts were fought by more

\footnotetext{
${ }^{68}$ We did not include exclusion of noncitizens from power, as long as these noncitizens hold passports of other states and are effectively able to return to their country of origin.

${ }^{69}$ Gleditsch et al. 2002.

${ }^{70}$ We drew primarily on version 3-2005b of the ACD data set, which provides two levels of conflict identification, a more general war ID number, and a disaggregated sub-ID.

${ }^{71}$ To avoid endogeneity, the power-access coding always reflects the situation before conflict onset in years that feature both conflict outbreak and power-status changes.
} 
than one group, we identify 146 group-level instances of ethnic conflict onset. Among these, 27 were fought by groups in power, 87 by powerless or discriminated groups, and 32 by autonomous groups. Half of these conflicts reached the standard threshold of civil war (that is, more than one thousand battle deaths in a year). In addition, the data set includes a distinction between secessionist and nonsecessionist conflict, to which we will return in our analysis of elite infighting.

\section{Variable Definitions and Data Sources}

Drawing on the EPR data set, we test all three hypotheses by measuring power access $(\mathrm{H} 1 \mathrm{a}, \mathrm{b}, \mathrm{c})$, mobilizational capacity $(\mathrm{H} 2)$, and prior conflict $(\mathrm{H} 3)$ for each politically relevant ethnic group in each year from 1946 to 2005.

The Excluded variable is a dichotomous indicator that indicates whether representatives of an ethnic category are discriminated against, are powerless, or have regional or separatist autonomy (H1a). To present a more nuanced picture, we also use dummy variables referring to specific EPR categories, that is, Junior Partner, Regional Autonomy, Separatist Autonomy, Powerless, and Discriminated. A Downgraded dummy variable identifies whether representatives of a group have experienced a decrease in power status during the previous two years (H1b), based on the EPR power-status categories. In our analysis of elite infighting, we add the Underrepresented variable, which indicates whether a junior coalition partner represents a larger ethnic group than a senior partner (H1c).

Furthermore, we evaluate group size with the logged variable Group Size, which uses the EPR estimate of demographic group size as a proportion of the total population of the country's politically relevant ethnic groups (H2). In order to test the influence of prior conflict, we use a variable Past Conflict that counts the number of conflicts that have already been fought in the name of the same ethnic group since the beginning of the sample period (H3). Finally, Peace Years counts the number of peaceful years since the last conflict or the beginning of the sample period. ${ }^{72}$

In order to control for country-level characteristics, we use two control variables throughout the article. Based on extensive robustness analysis, Hegre and Sambanis conclude that variables measuring wealth and population size have a powerful effect on civil war onset. ${ }^{73}$ Theresplines.

${ }^{72}$ Following Beck, Katz, and Tucker 1998, this indicator is tested together with three cubic

${ }^{73}$ Hegre and Sambanis 2006. 
fore we include measures of logged GDP per Capita and logged country Population Size, drawn from the Penn World Tables and World Bank sources. While several interpretations have been offered of the effects of income, our theory of ethnic politics expects that richer countries should have less conflict because they can afford to solve political conflicts through redistribution. ${ }^{74}$ Although a country's population size is usually significant in country-level studies of civil war onset, it is less clear what to expect here, especially since its robustness may simply reflect the fact that, all else equal, conflicts are more likely to occur in larger countries.

\section{Data Analysis}

We are now ready for a first evaluation of our three hypotheses relating to power access, mobilization capacity, and past conflict. The current section introduces statistical models that concern groups in all powerstatus categories, as well as more specific analysis of insurgencies in the name of excluded groups and infighting among power-sharing partners, since some of our causal mechanisms relate to specific actor types only.

\section{Descriptive ANALYSIS}

Our data set is structured in a group-country-year format, with 29,519 unique observations, including all politically relevant ethnic groups. Table 1 offers a first empirical assessment of the power-access hypothesis, H1. As expected, the frequency of conflict increases roughly with the degree of exclusion. Excluded groups are much more likely to experience a rebellion in their name ( 0.66 percent) compared with groups in power $(0.23$ percent $)$. A $\chi^{2}$-test confirms that this relationship is significant at $\mathrm{p}=0.0001$. With the exception of the category Regional Autonomy, which exhibits relatively less conflict than the power-sharing categories, the table also reveals that the conflict frequency falls steadily with increasing access from executive power. Because Separatist Autonomy differs from the other excluded categories in that the group has chosen to "exclude itself" from central state power, we list these at the end of the exclusion category. ${ }^{75}$

\footnotetext{
${ }^{74}$ Wimmer, Cederman, and Min 2009; cf. Sambanis 2004.

${ }^{75}$ Because all separatist groups get involved in violence at some point, the coding of regional versus separatist autonomy was verified case by case. Removing the separatist cases from the data set makes no difference to our other findings.
} 
TABLE 1

Ethnic Groups' Conflict Propensity by Category of Power Access

\begin{tabular}{lrcc}
\hline \hline & Group Years & Years of Ethnic-Confict Onset \\
\hline Included Groups & 11,622 & 27 & $0.23 \%$ \\
$\quad$ Monopoly $^{\mathrm{a}}$ & 1,672 & $\mathrm{n} / \mathrm{a}$ & $\mathrm{n} / \mathrm{a}$ \\
$\quad$ Dominant & 1,709 & $\mathrm{n} / \mathrm{a}$ & $\mathrm{n} / \mathrm{a}$ \\
Senior Partner & 2,884 & 9 & $0.31 \%$ \\
Junior Partner & 5,357 & 18 & $0.34 \%$ \\
Excluded Groups & 17,897 & 119 & $0.66 \%$ \\
Regional Autonomy & 5,433 & 13 & $0.24 \%$ \\
Powerless & 7,482 & 45 & $0.60 \%$ \\
Discriminated & 4,506 & 42 & $0.93 \%$ \\
Separatist Autonomy & 476 & 19 & $3.99 \%$ \\
Total & 29,519 & 146 & $0.46 \%$ \\
\hline
\end{tabular}

${ }^{a}$ No rebellion, by definition.

Going beyond descriptive statistics, we proceed with regression analysis to test the main hypotheses. Our standard framework consists of logit models with ethnic conflict onset as a dichotomous dependent variable. Because the causal logic during wars can be expected to differ from what it is in peacetime, we drop observations in which a war is currently ongoing and study only the risk of conflict onset during peacetime years. To account for the nonindependence of observations within countries, we present robust standard errors, clustered on the country unit.

\section{Analysis of All Groups}

Our main results are presented in Table 2. Using group-years as the unit of analysis, our analysis begins by including all politically relevant groups, except those that enjoyed Monopoly or Dominant status and by definition could not be associated with conflict against the state (see the first two columns). In order to operationalize the basic power access hypothesis, H1a, model 1 uses the Excluded dummy variable to identify those groups that have no access to central power. Based on this dichotomization, it is clear that rebellions in the name of excluded groups are much more likely than conflict in the name of included groups, thus supporting H1a. The Downgraded measure, which tests hypothesis $\mathrm{H} 1 \mathrm{~b}$, is also strongly confirmed in this analysis. In this case, the corresponding binary variable has an even stronger effect than the static exclusion measure. Turning to the test of the mobilization capacity hypothesis, H2, we also find solid evidence that, ceteris paribus, 
TABLE 2

Explaining Group-Level Ethnonationalist Conflict

\begin{tabular}{|c|c|c|c|c|}
\hline & (1) & (2) & (3) & (4) \\
\hline & All Groups & All Groups & $\begin{array}{l}\text { Excluded } \\
\text { Groups Only }\end{array}$ & $\begin{array}{c}\text { Elite } \\
\text { Infighting Only }\end{array}$ \\
\hline Excluded & $\begin{array}{l}1.2121^{* *} \\
(0.2668)\end{array}$ & & & \\
\hline Junior Partner & & $\begin{array}{c}0.3224 \\
(0.4056)\end{array}$ & & $\begin{array}{c}-0.1693 \\
(0.3926)\end{array}$ \\
\hline Only Local Power & & $\begin{array}{c}0.8321 \\
(0.5392)\end{array}$ & & \\
\hline Powerless & & $\begin{array}{l}1.2041^{* * *} \\
(0.4552)\end{array}$ & $\begin{array}{c}0.3866 \\
(0.3751)\end{array}$ & \\
\hline Discriminated & & $\begin{array}{l}1.6719^{* * *} \\
(0.4303)\end{array}$ & $\begin{array}{r}0.8603^{*} \\
(0.4237)\end{array}$ & \\
\hline Separatist & & $\begin{array}{l}3.2514^{* * *} \\
(0.6793)\end{array}$ & $\begin{array}{l}2.4769^{* *} \\
(0.8423)\end{array}$ & \\
\hline Downgraded & $\begin{array}{l}1.6419^{* *} \\
(0.3933)\end{array}$ & $\begin{array}{l}1.7590^{* * *} \\
(0.3920)\end{array}$ & $\begin{array}{l}1.8211^{* * *} \\
(0.4387)\end{array}$ & $\begin{array}{r}1.7526^{*} \\
(0.8353)\end{array}$ \\
\hline Log (Group Size) & $\begin{array}{l}0.2902^{* *} \\
(0.0783)\end{array}$ & $\begin{array}{l}0.3015^{* *} \\
(0.0829)\end{array}$ & $\begin{array}{l}0.3559^{\text {*** }} \\
(0.0926)\end{array}$ & $\begin{array}{c}-0.1834 \\
(0.2468)\end{array}$ \\
\hline Underrepresented & & & & $\begin{array}{l}0.1397^{* *} \\
(0.0321)\end{array}$ \\
\hline Past Conflict & $\begin{array}{l}0.8545^{* *} \\
(0.1727)\end{array}$ & $\begin{array}{l}0.6309^{* *} \\
(0.2387)\end{array}$ & $\begin{array}{c}0.6148 \\
(0.3245)\end{array}$ & $\begin{array}{c}0.6477 \\
(0.5621)\end{array}$ \\
\hline Log (GDP per Capita), Lagged & $\begin{array}{l}-0.3675^{* *} \\
(0.1023)\end{array}$ & $\begin{array}{l}-0.3346^{* * *} \\
(0.0920)\end{array}$ & $\begin{array}{l}-0.3396^{* *} \\
(0.1175)\end{array}$ & $\begin{array}{l}-0.2181 \\
(0.1545)\end{array}$ \\
\hline Log (Population), Lagged & $\begin{array}{l}-0.0046 \\
(0.0958)\end{array}$ & $\begin{array}{c}0.0220 \\
(0.0918)\end{array}$ & $\begin{array}{c}0.0766 \\
(0.1141)\end{array}$ & $\begin{array}{c}-0.1138 \\
(0.1158)\end{array}$ \\
\hline $\begin{array}{l}\text { Years since Last Conflict } \\
\text { Onset }\end{array}$ & $\begin{array}{l}-0.1542^{*} \\
(0.0725)\end{array}$ & $\begin{array}{c}-0.1398 \\
(0.0748)\end{array}$ & $\begin{array}{l}-0.1592 \\
(0.0840)\end{array}$ & $\begin{array}{l}-0.0112 \\
(0.1797)\end{array}$ \\
\hline Peace Years Splines & yes & yes & yes & yes \\
\hline Constant & $\begin{array}{c}-3.3042^{* *} \\
(1.2077)\end{array}$ & $\begin{array}{c}-4.1166^{* *} \\
(1.2531)\end{array}$ & $\begin{array}{l}-3.8561^{*} \\
(1.6007)\end{array}$ & $\begin{array}{l}-2.7547 \\
(2.0233)\end{array}$ \\
\hline Observations & 24445 & 24445 & 16498 & 7947 \\
\hline
\end{tabular}

Robust standard errors clustered on country in parentheses; ${ }^{* *} \mathrm{p}<0.01,{ }^{*} \mathrm{p}<0.05$

larger groups are more likely to experience a rebellion fought in their name. The analysis also confirms our path-dependency hypothesis, H3. As expected, the impact of Past Conflict is both large and significant. We also observe that the hazard rate declines during peaceful periods. 
Regarding the control variables, higher levels of GDP per Capita have a strong, negative influence on conflict onset. However, Population, which usually has strong effects in country-level analyses, fails to exhibit any significant or substantive effect.

As a way to compare the marginal effect of our key variables, we plot the difference that our main variables have on predicted conflict probabilities, holding other variables at their mean or modal values. Figure 2 displays the conflict propensities associated with included and excluded groups as a function of GDP per Capita. For both categories we observe an income effect, with higher risks of violent rebellion in countries with lower incomes, in line with previous findings. However, it is notable that excluded groups across all income levels are three times more likely to initiate conflict against the state as compared with included groups that enjoy representation at the center. The substantive effects of exclusion are especially pronounced in poor countries, where the already high baseline risk of violence is compounded for excluded groups. Our explanation is that in poor countries governments lack the resources necessary to co-opt leaders of protest movements that fuel resentment because of their exclusion from central government. Since the central state is all-decisive in poor countries, groups that lack representation and are marginalized in the distribution of state resources, government jobs, and public goods may have greater motives to take up arms. ${ }^{76}$ While not plotted in the figure, our other key variables also have very large effects on the risk of conflict: a downgraded power status and prior conflict history increases the likelihood of a conflict by 5.3 and 2.4 times respectively in comparison with included groups.

In a further effort to investigate $\mathrm{H} 1 \mathrm{a}$, model 2 introduces the more fine-grained power-access categories. It shows that the conflict-inducing impact of exclusion from state power represents more of a continuum than a dichotomy. According to our theory, conflict proneness should decrease gradually as the access of ethnic leaders to state power improves. Indeed, this is what we find. The coefficients range from a low and insignificant 0.32 for junior partners up to a highly significant 1.67 for discriminated groups and 3.25 for separatists. The latter category is especially conflict prone, not merely because of high motivation but also because separatism challenges the state to the highest possible degree, given that modern states are built on the principle of territorial sovereignty. Again, hypotheses $\mathrm{H} 1 \mathrm{~b}, \mathrm{H} 2$, and $\mathrm{H} 3$ are powerfully confirmed and the effect of the control variables remains virtually unchanged.

${ }^{76}$ Cf. Wimmer 2002, chap. 3. 


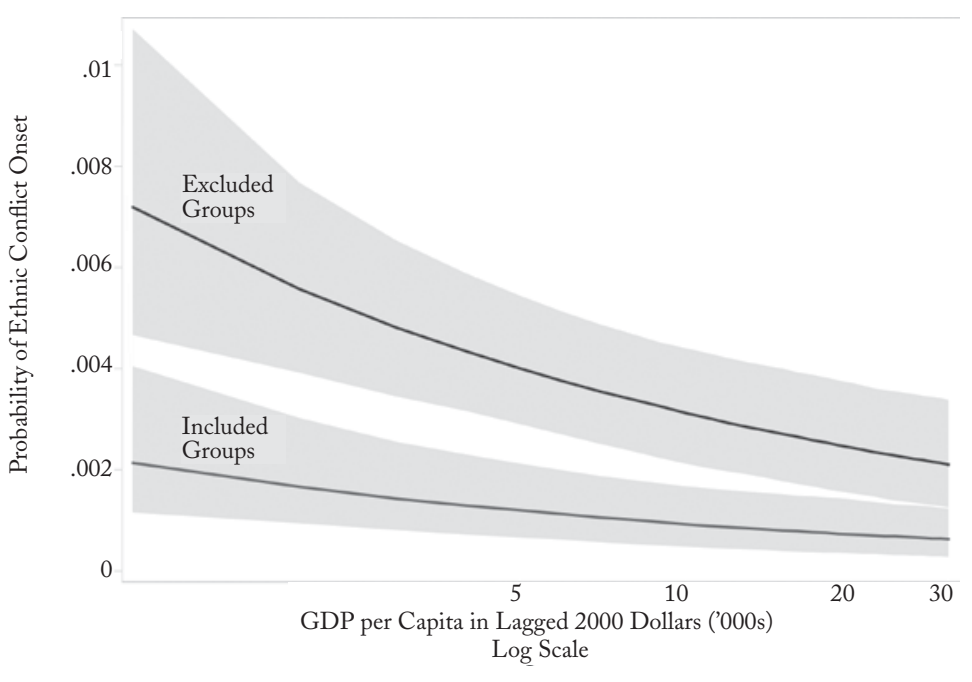

FIGURE 2

The Effect of GDP per Capita on Ethnic Groups'

Conflict Propensity ${ }^{\mathrm{a}}$

${ }^{\mathrm{a}}$ Shaded areas represent 95 percent confidence intervals.

So far, we have considered the relationship of all groups with the government, but there are reasons to believe that ethnic elites behave differently, depending on whether or not they are already represented in the central government. Therefore, we now consider excluded and included groups separately to identify the relation-specific effects that are partially concealed in the general analysis.

\section{ANALYSIS of ExCLUded Groups}

Once we restrict our analysis to rebellions in the name of excluded groups, we are able to specify a clear-cut actor constellation based on a center-periphery logic. Model 3 in Table 2 presents the empirical results of this analysis. Given the focus on excluded groups, we find smaller differences among the power-status categories. However, both Discrimination and Separatist Autonomy can be statistically distinguished from the baseline category Regional Autonomy, thus supporting hypothesis H1a. A recent Downgraded power status among these excluded groups increases conflict propensity significantly, in line with H1b. Compared with the general analysis, we find even more unambiguous evidence that large groups are more likely to experience conflict (H2). The influence of Prior Conflict remains significant (H3). Finally, the control variables behave similarly to the results noted in models 1 and 2 . 
Figure 3 offers a graphic depiction of how mobilizational capacity influences the risk of conflict for excluded groups. The plots, based on model 1, show that larger groups are more likely to initiate rebellion and that the risks are substantially higher for excluded groups that have had a prior conflict or have recently been downgraded in their power status. The effects of being downgraded are especially pronounced, though the effects are imprecisely estimated for larger group sizes.

\section{AnALYsis of InCluded Groups}

Finally, we shift our attention from excluded to included groups. Here we consider only cases of power sharing, that is, those that involve senior and junior partners of governing coalitions, because monopoly and dominant groups are directly identified with the government and thus by definition cannot challenge it. Our goal therefore is to understand why some power-sharing partners initiate conflict against a government in which they are represented. Following our hypothesis H1b and H1c, we expect that underrepresented power-sharing partners as well as those who have experienced a downgrading in their power position will be more likely to take up arms against other members of the governing coalition.

Before discussing results, a cautionary remark is in order. As indicated in Table 1 , there are very few cases of conflict instigated in the name of groups in power, only 27 onsets in 8,241 group-years. This means that the results of the statistical evaluation are likely to be sensitive to the coding of this small number of conflict events. With this caveat in mind, we turn to model 4 in Table 2. The results indicate that conflicts in the name of junior partner groups are not more frequent than those fought in the name of senior partners (H1a). However, the regression analysis suggests that a downgraded power status has an impact on conflict behavior, thus confirming H1b. We also get strong results for hypothesis $\mathrm{H} 1 \mathrm{c}$ that relate to resentment caused by underrepresentation within governing coalitions. Group size has no influence on the dependent variable in contrast to the effect for excluded groups in models $1-3$, suggesting that the mobilizational capacity argument does not hold for groups that already have access to the organizational apparatus of government. Furthermore, the path-dependency effect (H3) cannot be confirmed for the current subsample. Finally, we fail to find any significant effect for any of the control variables.

Given the rarity of conflict among groups in power, it is appropriate to examine individual cases. In particular, it should be noted that the events influencing the coefficients on downgraded power status $(\mathrm{H} 1 \mathrm{~b})$ 

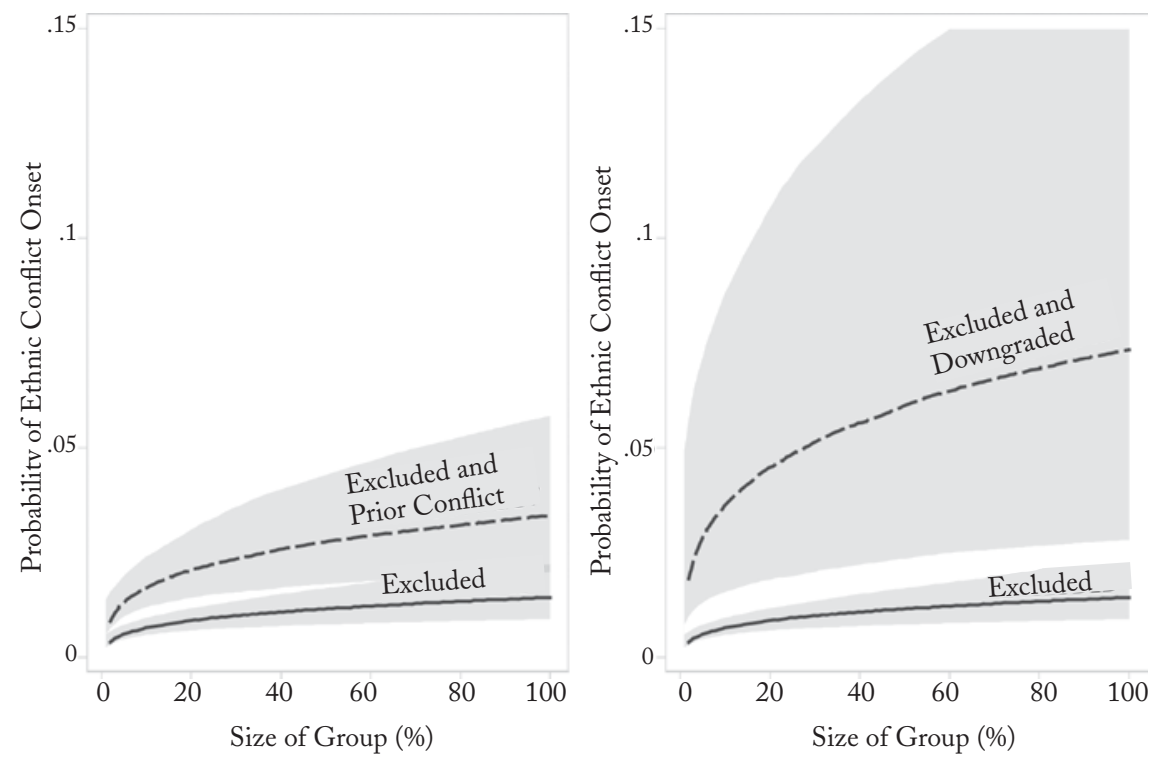

FIGURE 3

The Effect of Excluded Ethnic Groups' Size on Their Conflict Propensity a

${ }^{\mathrm{a}}$ Shaded areas represent 95 percent confidence intervals.

and underrepresentation (H1c) refer to cases of nonsecessionist conflict only. The ten secessionist conflicts are not well predicted by our model. Typically, these secessionist conflicts involved radicalized splinter groups that were dissatisfied with the power-sharing deal offered by the government and therefore resorted to violence; among these groups were the United Liberation Front of Assam, ${ }^{77}$ the Sikh Sangat organization, ${ }^{78}$ or the Albanian UCK/KLA rebels in Macedonia. ${ }^{79}$ These cases illustrate a general limitation of our research design. Different organizations claim to represent the interests of an ethnic group, and if one organization participates in government, this does not prevent others from taking an oppositional stand to mount a rebellion in the name of "true" group interests. From a theoretical perspective, this outcome is not surprising because it is, after all, parties and their representatives that participate in government rather than ethnic groups.

\footnotetext{
${ }^{77}$ Baruah 1994.

${ }^{78}$ Chima 1994.

${ }^{79}$ Lund 2005.
} 
In other cases, the fear of future domination by coalition partners triggered secessionist bids that turned violent, as in former Yugoslavia and Bosnia and Herzegovina. ${ }^{80}$ In principle, the fear of domination by ethnic others in the future-rather than its actual experience-is consistent with our theory, although it cannot be captured with existing indicators without addressing severe endogeneity problems. In a complementary analysis on the country level, we show that such fears and the corresponding secessionist conflicts are more likely in states with a short history of direct rule by the political center. ${ }^{81}$

The seventeen nonsecessionist instances of elite infighting are somewhat more numerous but still warrant case-by-case analysis. How supportive is the evidence in favor of the main hypotheses relating to a fall in power status (H1b)? We find only two instances of conflicts within two years of a downgraded power status. After a long period of dominance by President Eyadéma, who favored his own Kabré group in Togo's army and administration, he came under pressure to democratize and had to agree to power sharing in 1991. Despite their status as senior partner, he and his entourage in the army became unhappy with the power-sharing arrangement and launched a coup later that same year. Meanwhile, the 1984 coup in Cameroon can be seen as a reaction to the shift of power from the Fulani-dominated regime of President Ahidjo to the government of Biya, a Beti politician. ${ }^{82}$

Regarding conflicts driven by underrepresentation within the governing coalition (H1c), the data point us to three potential cases, namely, the Sara 1991 rebellion in Chad, the Hutu 1991 uprising in Burundi, and Shiite participation in the Lebanese civil war in 1975. Rather than being directly motivated by underrepresentation, the first of these three conflicts appears to be more related to long-term frustrations felt by the Sara, who had dominated the state's early history from independence in 1960 through $1978,{ }^{83}$ and thus is in line with the downgrading hypothesis (H1b). ${ }^{84}$ In the other two events, however, the conflict is indeed related to the underrepresentation mechanism. In 1991 rebels who claimed to represent the Hutu majority launched an armed struggle against the Tutsi-dominated power-sharing arrangement. ${ }^{85}$ In Lebanon, the Shiite political elite were increasingly resentful that the Maronites were overrepresented in the traditional consociational

\footnotetext{
${ }^{80}$ Kalyvas and Sambanis 2005.

${ }^{81}$ Wimmer, Cederman, and Min 2009.

${ }^{82}$ Mehler 1993.

${ }^{83}$ Decalo 1980.

${ }^{84}$ The Downgraded variable does not pick up this case because it is based on a two-year window.

${ }^{85}$ Lemarchand 1994.
} 
arrangement guaranteeing them the presidency, especially because the share of the Shiite population had increased in prior decades. ${ }^{86}$

According to our data, the influence of past civil conflict plays a role in some cases of elite infighting. There are obvious instances, such as the rebellions in Chad that happened against the backdrop of a longlasting civil war. Nor can there be any doubt that the Hutu defection from the Tutsi-dominated governing coalition in 1991 was influenced by memories of past massacres. A similar argument can be made with respect to the failure of the power-sharing arrangement in Lebanon in 1975, because Shiite and Sunni leaders had already mobilized their constituencies in the conflict against the Maronite elite in 1958. In all three cases the past conflict variable thus picks up meaningful historical processes.

To sum up, the historical evidence in support of model 4 is strong, although the results are driven exclusively by nonsecessionist conflicts. The hypotheses relating to the downgrading and underrepresentation mechanisms $(\mathrm{H} 1 \mathrm{~b}, \mathrm{c})$ are tentatively supported by a case-by-case inspection of the nonsecessionist cases of elite infighting.

\section{Sensitivity Analysis}

Table 3 presents robustness checks of our primary findings based on model 1 of Table 2 . We start by considering the robustness of model 1 to the inclusion of dummy variables that divide countries into six world regions, using the Western states as the reference category (see model 5). The regional coefficients for North Africa and the Middle East, sub-Saharan Africa, and Asia are positive and significant at the $p=0.10$ level. More important, we do not detect any major differences in the effect of our main explanatory variables: exclusion, downgraded, group size, and conflict history remain powerful even after controlling for differences across world regions (see hypotheses 1-3). In contrast, the GDP variable loses some of its impact and is now significant at the $p=0.053$ level.

To further control for local-level factors, we introduce a model with country fixed effects (see model 6), allowing the constant to vary independently for each state in which an ethnic conflict has occurred. This design captures time-invariant country-specific features that are not captured by our independent variables. The results confirm the robustness of our main hypotheses, except $\mathrm{H} 3$. Whereas the status vari-

${ }^{86}$ Makdisi and Sadaka 2005, 61. 
TABLE 3

SENSITIVITY ANALYsis

\begin{tabular}{|c|c|c|c|}
\hline & (1) & (2) & (3) \\
\hline & Region Controls & $\begin{array}{c}\text { Country Fixed } \\
\text { Effects }\end{array}$ & $\begin{array}{c}\text { High-Intensity } \\
\text { Onsets Only }\end{array}$ \\
\hline Excluded & $\begin{array}{l}1.2534^{* *} \\
(0.2652)\end{array}$ & $\begin{array}{l}1.3262^{* *} \\
(0.2960)\end{array}$ & $\begin{array}{l}1.3904^{\text {*** }} \\
(0.3780)\end{array}$ \\
\hline Downgraded & $\begin{array}{l}1.5911^{* *} \\
(0.4001)\end{array}$ & $\begin{array}{l}1.5821^{* * *} \\
(0.3117)\end{array}$ & $\begin{array}{l}1.8696^{\text {*** }} \\
(0.4909)\end{array}$ \\
\hline Log (Group Size) & $\begin{array}{l}0.2906^{* *} \\
(0.0893)\end{array}$ & $\begin{array}{l}0.2595^{* *} \\
(0.0785)\end{array}$ & $\begin{array}{l}0.3919^{\text {*** }} \\
(0.0970)\end{array}$ \\
\hline Past Conflict & $\begin{array}{l}0.8388^{* *} \\
(0.1662)\end{array}$ & $\begin{array}{c}0.1138 \\
(0.2378)\end{array}$ & $\begin{array}{r}0.6797^{*} \\
(0.2692)\end{array}$ \\
\hline Log (GDP per Capita), Lagged & $\begin{array}{c}-0.2232 \\
(0.1155)\end{array}$ & $\begin{array}{c}0.0228 \\
(0.2400)\end{array}$ & $\begin{array}{l}-0.5069^{* *} \\
(0.1243)\end{array}$ \\
\hline Log (Population), Lagged & $\begin{array}{c}-0.0335 \\
(0.0955)\end{array}$ & $\begin{array}{c}0.3558 \\
(0.3573)\end{array}$ & $\begin{array}{c}-0.0172 \\
(0.0995)\end{array}$ \\
\hline Years since Last Conflict Onset & $\begin{array}{l}-0.1582^{*} \\
(0.0731)\end{array}$ & $\begin{array}{l}-0.1432^{*} \\
(0.0624)\end{array}$ & $\begin{array}{l}-0.1888 \\
(0.0969)\end{array}$ \\
\hline North Africa and Middle East & $\begin{array}{c}1.2148 \\
(0.6450)\end{array}$ & & \\
\hline Latin America & $\begin{array}{c}0.3654 \\
(0.6992)\end{array}$ & & \\
\hline Sub-Saharan Africa & $\begin{array}{c}1.1917 \\
(0.6549)\end{array}$ & & \\
\hline Eastern Europe & $\begin{array}{c}0.9736 \\
(0.6438)\end{array}$ & & \\
\hline Asia & $\begin{array}{c}1.3391 \\
(0.6914)\end{array}$ & & \\
\hline Peace Years Splines & yes & yes & yes \\
\hline Country Fixed Effects & no & yes & no \\
\hline Decade Fixed Effects & no & no & no \\
\hline Constant & $\begin{array}{l}-5.2080^{* *} \\
(1.5947)\end{array}$ & $\begin{array}{r}-25.1064 \\
(0.0000)\end{array}$ & $\begin{array}{c}-2.8117^{*} \\
(1.3791)\end{array}$ \\
\hline Observations & 24445 & 15734 & 24445 \\
\hline
\end{tabular}

Robust standard errors clustered on country in parentheses; ${ }^{* *} \mathrm{p}<0.01,{ }^{*} \mathrm{p}<0.05$

ables and size indicator influence the dependent variable, the impact of past conflict cannot be statistically confirmed due to the low variance among the country-observations that experienced conflict. Moreover, in what is a clear shortcoming, fixed-effects estimation excludes from the analysis all countries that never experience conflict. ${ }^{87}$

${ }^{87}$ Beck and Katz 2001. 
In order to test whether our models are sensitive to the intensity of conflicts, we replace the coding of the dependent variable based on the twenty-five battle deaths threshold with one that conforms to the one thousand battle deaths threshold conventionally used to define civil wars, while otherwise keeping model 1 unchanged. Model 7 shows that our results hold in predicting the onset of this smaller set of seventysix high-intensity conflicts. The variables associated with the main hypotheses retain their effect, as does the GDP per Capita variable.

Our results are also robust to various changes in the operationalization of our key variables (results not shown). For example, varying the two-year window used to calculate the Downgraded variable to one-, three-, four-, or five-year windows makes no substantive difference for our results. As discussed in the context of elite infighting, the coding of our dependent variable allows us to check whether our findings differ for secessionist and nonsecessionist conflicts. Whereas this is the case for elite infighting, all the main hypotheses hold robustly for secessionist and nonsecessionist conflicts fought in the name of excluded groups.

Finally, our results are also robust to controls for regime type and time trends (results not shown). Democracies are no less likely than autocracies to experience ethnic conflict, contrary to the expectations of democratic civil peace theory. The relationship between anocracy and ethnic conflict is less clear and depends on whether anocracy is defined using the standard Polity scores or based on alternative coding schemes. ${ }^{88}$ Given the long time frame of our study, we examined the potential effects of temporal and geopolitical trends by adding a cold war dummy, a calendar year variable, and decade fixed effects. None of these variables reduces the statistical or substantive significance of our main findings.

\section{Conclusion}

In this article we have investigated the influence of ethnic power inequality on civil war and found that exclusion and competition along ethnic lines are strongly associated with internal conflict. Rather than continuing to debate whether or not ethnic diversity or polarization breeds conflict, quantitative researchers might want to try identifying

\footnotetext{
${ }^{88}$ Vreeland 2008 reports that Polity-based codings of regime type are endogenous to civil war and offers corrected regime variables. In our model, anocracies classified using standard Polity scores are significantly more conflict prone than other regime types, but the significance disappears when using the Vreeland coding.
} 
those ethnic constellations of power that are particularly war prone. The article contributes to this endeavor by showing that once ethnic politics is properly conceptualized and measured, it is indeed possible to identify the conditions under which ethnonationalist civil wars are more likely to break out. Large ethnic groups that are excluded from state power or underrepresented in government are much more likely to challenge the regime's insiders through violent means. Also in keeping with our theoretical expectations, a loss of power in recent history or previous conflict further increases the likelihood of armed conflict.

Readers who are familiar with the qualitative scholarship on ethnic conflict may not be surprised that representatives of ethnic groups with less access to power are more likely to challenge the government. However, this finding is far from trivial. Indeed, the most widely cited articles in the recent civil war literature contend that ethnic diversity is unrelated to the likelihood of conflict and conclude that ethnicity thus does not matter for understanding war and peace. ${ }^{89}$ Introducing a stark opposition between matters of motivation and legitimacy ("grievances"), on the one hand, and factors related to the military and economic feasibility of insurgencies, on the other hand, these scholars argue that ethnic grievances are too ubiquitous to explain the rare event of civil war. Without denying the relevance of feasibility mechanisms, our findings show that ethnicity should not be discounted as an explanatory factor in the study of civil wars. We demonstrate empirically how the logics of contention and mobilization lead ethnically defined actors who are excluded from state power into armed conflict. Roughly half of the conflicts fought since the Second World War can be linked to this dynamic of ethnopolitical struggle for state power.

How do our findings relate to existing research on ethnic conflict? As suggested above, past quantitative tests of how political exclusion and discrimination relate to the propensity of violence have produced conflicting results. We argue that sample selection and data quality problems are responsible for this inconclusiveness and believe that our new data set on ethnic power relations (EPR) represents significant progress by enabling more precise coding of political representation in state governments, including that of dominant majorities or power-sharing partners. Since the EPR data set is time sensitive, it also permits tracing changes in power access and determining whether such changes affect the conflict dynamic over time. On the basis of this improved data set, we are able to establish an unequivocal relationship between the degree of access to state power and the likelihood of armed rebellion.

\footnotetext{
${ }^{89}$ Fearon and Laitin 2003; Collier and Hoeffler 2004.
} 
While improving on previous studies of ethnic conflict, our research also has limitations that we intend to address in the future. First, despite our efforts to capture time-sensitive mechanisms, our focus has been mostly on structural conditions rather than on dynamic and strategic processes of contention and mobilization. Second, we have not tried to explain changes in power structures and the political relevance of different ethnic categories but have treated these instead as exogenously given. Third, due to limited data availability, we have refrained from analyzing the effects of cross-border relationships between ethnic kin, settlement patterns, and institutional factors relating to party systems and electoral institutions. Indeed, this study is written as an invitation to fill these gaps by collecting more precise data on ethnic organizations, their mobilizational capacities and power resources, and their interactions with each other as well as with nonethnic organizations and governmental actors, inside or across state borders. Ideally, such data would make it possible to develop a fully processual theory that will allow us to analyze ethnic conflicts as a specific conjuncture in the ongoing struggle over state power between dynamically evolving sets of actors.

\section{REFERENCES}

Anderson, Benedict. 1991. Imagined Communities: Reflections on the Origin and Spread of Nationalism. London: Verso.

Baruah, Sanjib. 1994. "The State and Separatist Militancy in Assam: Winning a Battle and Losing the War?" Asian Survey 34, no. 10: 863-77.

Beck, Nathaniel, and Jonathan N. Katz. 2001. "Throwing Out the Baby with the Bath Water: A Comment on Green, Kim, and Yoon.” International Organization 55, no. 2 (Spring): 487-95.

Beck, Nathaniel, Jonathan N. Katz, and Richard Tucker. 1998. "Taking Time Seriously: Time-Series-Cross-Section Analysis with a Binary Dependent Variable." American Journal of Political Science 42, no. 4: 1260-88.

Beissinger, Mark R. 2002. Nationalist Mobilization and the Collapse of the Soviet Union. Cambridge: Cambridge University Press.

Birnir, Jóhanna Kristín. 2007. Ethnicity and Electoral Politics. Cambridge: Cambridge University Press.

Blimes, Rand. 2006. "The Indirect Effect of Ethnic Heterogeneity on the Likelihood of Civil War Onset." Journal of Conflict Resolution 50, no. 4: 536-47.

Brancati, Dawn. 2006. "Decentralization: Fueling the Fire or Dampening the Flames of Ethnic Conflict and Secessionism." International Organization 60, no. 3: 651-85.

Brass, Paul. 1991. Ethnicity and Nationalism: Theory and Comparison. Newbury Park: Sage.

Breuilly, John. 1994. Nationalism and the State, 2nd ed. Chicago: University of Chicago Press. 
Brubaker, Rogers. 1996. Nationalism Reframed: Nationhood and the National Question in the New Europe. Cambridge: Cambridge University Press.

- 2004. Ethnicity without Groups. Cambridge: Harvard University Press.

Brubaker, Rogers, and David D. Laitin. 1998. "Ethnic and Nationalist Violence." Annual Review of Sociology 24: 423-52.

Buhaug, Halvard, Lars-Erik Cederman, and Jan Ketil Rød. 2008. "Disaggregating Ethno-Nationalist Civil Wars: A Dyadic Test of Exclusion Theory." International Organization 62, no. 3 (July): 531-51.

Cederman, Lars-Erik. 1997. Emergent Actors in World Politics: How States and Nations Develop and Dissolve. Princeton: Princeton University Press.

Cederman, Lars-Erik, Halvard Buhaug, and Jan Ketil Rød. 2009. "Ethno-Nationalist Dyads and Civil War: A GIS-Based Analysis." Journal of Conflict Resolution 53, no. 4: 496-525.

Cederman, Lars-Erik, and Luc Girardin. 2007. "Beyond Fractionalization: Mapping Ethnicity onto Nationalist Insurgencies." American Political Science Review 101, no. 1: 173-85.

Cederman, Lars-Erik, Luc Girardin, and Kristian Skrede Gleditsch. 2009. "Ethnonationalist Triads: Assessing the Influence of Kin Groups on Civil Wars." World Politics 61, no. 3 (July): 403-37.

Cetinyan, Rupen. 2002. "Ethnic Bargaining in the Shadow of Third-Party Intervention." International Organization 56, no. 3: 645-77.

Chima, Jugdep S. 1994. "The Punjab Crisis: Governmental Centralization and Akali-Center Relations.” Asian Survey 34, no. 10: 847-62.

Collier, Paul, and Anke Hoeffler. 2004. "Greed and Grievance in Civil Wars." Oxford Economic Papers 56, no. 4: 563-95.

Cohen, Frank S. 1997. "Proportional versus Majoritarian Ethnic Conflict Management in Democracies." Comparative Political Studies 30, no. 5: 607-30.

Cunningham, David E., Kristian Skrede Gleditsch, and Idean Salehyan. 2009. "It Takes Two: A Dyadic Analysis of Civil War Duration and Outcome." Journal of Conflict Resolution 53, no. 4: 570-97.

Decalo, Samuel. 1980. "Chad: The Roots of Center-Periphery Strife." African Affairs 79, no. 317: 490-509.

De Figueiredo, Rui, and Barry Weingast. 1999. “The Rationality of Fear: Political Opportunism and Ethnic Conflict." In Barbara Walter and Jack Snyder, eds., Civil Wars, Insecurity, and Intervention. New York: Columbia University Press.

DeNardo, James. 1985. Power in Numbers: The Political Strategy of Protest and Rebellion. Princeton: Princeton University Press.

Fearon, James D., and David D. Laitin. 2003. "Ethnicity, Insurgency, and Civil War." American Political Science Review 97, no. 1: 75-90.

Fox, Jonathan. 2000. "The Effects of Religious Discrimination on Ethno-Religious Protest and Rebellion." Journal of Conflict Studies 20, no. 1.

Gellner, Ernest. 1983. Nations and Nationalism. Ithaca, N.Y.: Cornell University Press.

Gleditsch, Nils Petter, Peter Wallensteen, Mikael Eriksson, Margareta Sollenberg, and Håvard Strand. 2002. "Armed Conflict 1946-2001: A New Dataset." Journal of Peace Research 39, no. 5: 615-37.

Gurr, Ted Robert. 1993a. Minorities at Risk: A Global View of Ethnopolitical Conflicts. Washington, D.C.: United States Institute of Peace Press. 
.1993b. "Why Minorities Rebel: A Global Analysis of Communal Mobilization and Conflict since 1945." International Political Science Review 14, no. 2: $161-201$

- 2000. Peoples versus States: Minorities at Risk in the New Century. Washington, D.C.: United States Institute of Peace Press.

Hardin, Russell. 1995. One for All: The Logic of Group Conflict. Princeton: Princeton University Press.

Hechter, Michael. 2001. Containing Nationalism. Oxford: Oxford University Press.

Hechter, Michael, and Dina Okamoto. 2001. "Political Consequences of Minority Group Formation." Annual Review of Political Science 4: 189-215.

Hegre, Håvard, Tanja Ellingsen, Scott Gates, and Nils Petter Gleditsch. 2001. "Toward a Democratic Civil Peace? Democracy, Political Change, and Civil War, 1816-1992." American Political Science Review 95, no. 1: 33-48.

Hegre, Håvard, and Nicholas Sambanis. 2006. "Sensitivity Analysis of Empirical Results on Civil War Onset." Journal of Conflict Resolution 50, no. 4: 508-35.

Horowitz, Donald L. 1985. Ethnic Groups in Conflict. Berkeley: University of California Press.

Jackman, Robert W. 1993. Power without Force. Ann Arbor: University of Michigan Press.

Jenne, Erin K. 2007. Ethnic Bargaining: The Paradox of Minority Empowerment. Ithaca, N.Y.: Cornell University Press.

Kalyvas, Stathis N. 2006. The Logic of Violence in Civil War. Cambridge: Cambridge University Press.

— 2007. "Civil Wars." In Carles Boix and Susan Carol Stokes, eds., The Oxford Handbook of Comparative Politics. Oxford: Oxford University Press.

Kalyvas, Stathis N., and Matthew Adam Kocher. 2007. "How 'Free' Is Free Riding in Civil Wars? Violence, Insurgency, and the Collective Action Problem." World Politics 59, no. 2 (January): 177-216.

Kalyvas, Stathis N., and Nicholas Sambanis. 2005. "Bosnia's Civil War: Origins and Violence Dynamics." In Paul Collier and Nicholas Sambanis, eds. Understanding Civil War: Evidence and Analysis, vol. 2. Washington, D.C.: World Bank.

Kedourie, Elie. 1960. Nationalism. New York: Praeger.

Kemper, Theodore D. 1978. A Social Interaction Theory of Emotions. New York: John Wiley.

Laitin, David D. 1995. "National Revivals and Violence." Archives Européennes de Sociologie 36, no. 1: 3-43.

Lake, David A., and Donald Rothchild, eds. 1998. The International Spread of Ethnic Conflict: Fear, Diffusion, and Escalation. Princeton: Princeton University Press.

Lemarchand, René. 1994. Burundi: Ethnic Conflict and Genocide. Cambridge: Cambridge University Press.

Lund, Michael S. 2005. "Greed and Grievance Diverted: Macedonia Avoided Civil War, 1990-2001.” In Paul Collier and Nicholas Sambanis, eds., Understanding Civil War: Evidence and Analysis, vol. 2. Washington, D.C.: World Bank.

McCarthy, John, and Mayer N. Zald. 1977. "Resource Mobilization and Social Movements: A Partial Theory." American Journal of Sociology 82, no. 6: 1212-41. 
Makdisi, Samir, and Richard Sadaka. 2005. "The Lebanese Civil War, 1975-90.” In Paul Collier and Nicholas Sambanis, eds., Understanding Civil War: Evidence and Analysis, vol. 2. Washington, D.C.: World Bank.

Mehler, Andreas. 1993. Kamerun in der Ära Biya: Bedingungen, erste Schritte und Blockaden einer demokratischen Transition. Hamburg: Institut für Afrika-Kunde.

Migdal, Joel S. 1988. Strong Societies and Weak States. Princeton: Princeton University Press.

Min, Brian, Lars-Erik Cederman, and Andreas Wimmer. 2009. "Ethnic Exclusion, Economic Growth, and Civil War.” Manuscript, UCLA.

Montalvo, José G., and Marta Reynal-Querol. 2005. "Ethnic Polarization, Potential Conflict, and Civil Wars." American Economic Review 95, no. 3: 796-816.

Olzak, Susan. 2006. The Global Dynamics of Racial and Ethnic Mobilization. Stanford, Calif.: Stanford University press.

Petersen, Roger. 2002. Understanding Ethnic Violence: Fear, Hatred, and Resentment in Twentieth-Century Eastern Europe. Cambridge: Cambridge University Press.

Posen, Barry R. 1993. “The Security Dilemma and Ethnic Conflict.” In Michael E. Brown, ed., Ethnic Conflict and International Security. Princeton: Princeton University Press.

Posner, Daniel N. 2004. "Measuring Ethnic Fractionalization in Africa." American Journal of Political Science 48, no. 4: 849-63.

Regan, Patrick, and Daniel Norton. 2005. "Greed, Grievance, and Mobilization in Civil Wars." Journal of Conflict Resolution 49, no. 3: 319-36.

Rothschild, Joseph. 1981. Ethnopolitics: A Conceptual Framerwork. New York: Columbia University Press.

Rydgren, Jens. 2007. "The Power of the Past: A Contribution to a Cognitive Sociology of Ethnic Conflict." Sociological Theory 25, no. 3: 225-44.

Saideman, Stephen M. 2002. "Discriminating in International Relations: Analyzing External Support for Ethnic Groups.” Journal of Peace Research 39, no. 1: $27-50$.

Saideman, Stephen M., and R. William Ayres. 2000. "Determining the Causes of Irredentism: Logit Analyses of Minorities at Risk Data from the 1980s and 1990s." Journal of Politics 62, no. 4: 1126-44.

Salehyan, Idean. 2009. Rebels without Borders: Transnational Insurgencies in World Politics. Ithaca, N.Y.: Cornell University Press.

Sambanis, Nicholas. 2001. "Do Ethnic and Nonethnic Civil Wars Have the Same Causes? A Theoretical and Empirical Inquiry." Journal of Conflict Resolution 45, no. 3: 259-82.

. 2004. "What Is Civil War? Conceptual and Empirical Complexities of an Operational Definition." Journal of Conflict Resolution 48, no. 3: 814-58.

Tarrow, Sidney. 2007. "Inside Insurgencies: Politics and Violence in an Age of Civil War." Perspectives on Politics 5, no. 3: 587-600.

Tilly, Charles. 1978. From Mobilization to Revolution. New York: McGraw-Hill.

Tilly, Charles, and Sidney Tarrow. 2006. Contentious Politics. Boulder, Colo.: Paradigm Press.

Tir, Jaroslav, and Michael Jasinski. 2008. "Domestic-Level Diversionary Theory of War: Targeting Ethnic Minorities." Journal of Conflict Resolution 52, no. 5: 641-64. 
Toft, Monica Duffy. 2003. The Geography of Ethnic Violence: Identity, Interests, and the Indivisibility of Territory. Princeton: Princeton University Press.

Turner, Jonathan H., and Jan E. Stets. 2005. The Sociology of Emotions. Cambridge: Cambridge University Press.

Vreeland, James Raymond. 2008. "The Effect of Political Regime on Civil War: Unpacking Anocracy." Journal of Conflict Resolution 52, no. 3: 401-25.

Waldmann, Peter. 2004. "The Asymmetry between the Dynamics of Violence and the Dynamics of Peace: The Case of Civil Wars." In Andreas Wimmer, Richard Goldstone, Donald L. Horowitz, Ulrike Joras, and Conrad Schetter, eds., Facing Ethnic Conflicts: Toward a New Realism. Lanham, Md.: Rowman and Littlefield.

Walter, Barbara. 2004. "Does Conflict Beget Conflict? Explaining Recurring Civil War." Journal of Peace Research 41, no. 3: 371-88.

- 2006a. "Information, Uncertainty, and the Decision to Secede." International Organization 60, no. 1:105-35.

—. 2006b. "Building Reputation: Why Governments Fight Some Separatists but Not Others." American Journal of Political Science 50, no. 2: 313-30.

Weber, Max. 1978. Economy and Society: An Outline of Interpretative Sociology. Berkeley: University of California Press.

Weidmann, Nils B. 2009. "Geography as Motivation and Opportunity: Group Concentration and Ethnic Conflict." Journal of Conflict Resolution 53, no. 4: 526-43.

Weiner, Myron. 1971. "The Macedonian Syndrome: An Historical Model of International Relations and Political Development." World Politics 23, no. 4 (October): 665-83.

Wimmer, Andreas. 2002. Nationalist Exclusion and Ethnic Conflict: Shadows of Modernity. Cambridge: Cambridge University Press.

- 2008. "The Making and Unmaking of Ethnic Boundaries. A Multi-level Process Theory." American Journal of Sociology 113, no. 4: 970-1022.

Wimmer, Andreas, Lars-Erik Cederman, and Brian Min. 2009. "Ethnic Politics and Armed Conflict: A Configurational Analysis." American Sociological Review 74, no. 2: 316-37.

Wimmer, Andreas, and Brian Min. 2006. "From Empire to Nation-State. Explaining Wars in the Modern World, 1816-2001." American Sociological Review 71, no. 6: 867-97.

Young, Crawford. 1976. The Politics of Cultural Pluralism. Madison: University of Wisconsin Press. 